\title{
11
}

\section{A paradox of tradition in a modernising society: chiefs and political development in Fiji}

\section{Robert Norton}

This chapter went to press after the most remarkable parliamentary elections in Fiji's history gave victory to the People's Coalition, a loose alliance between the predominantly Indian Fiji Labour Party and two Fijian parties, the Fijian Association Party and the Party of National Unity, which massively defeated a coalition of the Fijian SVT and the Indian NFP, led by Rabuka and Reddy. For the first time Fiji has an Indian prime minister, Labour's leader Mahendra Chaudhry, who heads a cabinet with a majority of Fijian ministers. Rabuka was returned to parliament, but resigned to accept the chairmanship of the Council of Chiefs.

The defeat of Rabuka's government was caused mainly by an unprecedented political fragmentation among the Fijians. There was widespread disaffection over the failure of the government to improve living standards and economic opportunities, and resentment at Rabuka's personal role in the constitutional reform which many of this opponents denounced as a betrayal of the promise of his coups. One of the starkest ironies of the elections was the Labour Party's gain from Fijian ethnicist opposition to the constitutional reform to which the party had, in its universalist ideology, been so radically committed.

To some extent, Labour's victory also reflects the widening of a popular base of shared inter-ethnic interests at a time of growing 
anxiety and anger about economic conditions, and there is potential in these concerns for a strengthening of the party's multi-ethnic character. But Labour depends most on an unstable alliance of groups with contradictory agendas. Chaudhry must contend with the ever-present potential for ethnic conflict within his coalition on such sensitive matters as land reform where he aims to improve the security of the Indian tenants, and over rivalries for cabinet and other government posts.

Some aspects of the election aftermath reinforce my argument about the significance of the chiefs in contemporary political process. Fiji's president, Ratu Sir Kamisese Mara, refused a request by the Fijian Association Party, Labour's principal partner, that its own leader, Adi Kuini Speed (widow of the overthrown Dr Bavadra) be appointed prime minister. Chaudhry warmly acknowledged Mara's decisive influence in persuading the FAP to accept his leadership, and he sought to dispel Fijian anxieties 'about my intentions and those of my government' in a speech to a specially convened meeting of the Council of Chiefs. It was clear that Chaudhry viewed the occasion as crucial for strengthening the legitimacy of his leadership of the nation. In its fullsome rhetoric of respect, his address to the chiefs echoed that of Jai Ram Reddy, which had facilitated the constitutional reform.

Chaudhry reaffirmed Reddy's 'assurances...that all communities...look to this great venerable institution for leadership and guidance in the good governance and well-being of our nation' (Fiji Times, 14 June 1999:22-3). He promised to protect and advance indigenous interests and to consult with the chiefs.

As chairman of the Council of Chiefs, Rabuka, still a potent icon of ethnic power and therefore well-suited for the office despite his lack of chiefly rank, will have an enhanced capacity to encourage Fijians to either oppose or cooperate with Chaudhry's government-at times to be a focal point of ethnicist resistance, and sometimes a mediator encouraging accommodation. In this respect Rabuka's new position may resemble that which leading chiefs have long taken in the national political arena. The crisis of expiring Indian farm leases, aggravated by Fijian resentment of the election outcome and threatening the national economic well-being, might prove to be his first challenge in this role. Some chiefs reacted against the Labour triumph by declaring that leases in their districts would not be renewed: 'Fijians have given up the political control of their native land. They are not prepared to give up anything else. They will now be reluctant to share with others' (Tui Wailevu, Daily Post, 23 June 1999). 
A principle of shared national citizenship is a necessary condition for equitable development to meet basic human needs. In Fiji, the achievement of such a principle, still problematic nearly 30 years after political independence, must be based on the ideological and institutional management of deep ethnic difference. The centrality of chieftainship in framing Fijian ethnic identity has favoured this by constraining conflict with Indians and facilitating agreements for sharing land and political power. My theme refutes a commonly held view that the chiefs have been an obstacle to national integration.

Fijian chiefs and chiefly councils, as they were partly refashioned into 'neo-traditional' instruments of colonial rule, have been depicted in modernist academic discourse in terms of self-serving 'aristocratic' interests. Some writers have interpreted the military coups as primarily supporting the interests of 'the eastern chiefly élite' who stand in the way of unity among ordinary Fijians and Indians. These characterisations, mainly by political scientists, have misrepresented the social character of the Fijian élites who benefited from the coups (mostly commoners) and misled us about the place of chiefly leadership in shaping foundations for a nation state (Robertson and Tamanisau 1988; Lawson 1991; Sutherland 1992). While chiefs can certainly be said to have 'vested interests' (for example a privileged share in land rents), to focus attention on these will not illuminate the chiefs' significance in Fijian group and ethnic identities and in interethnic accommodation. Anthropologists and historians have studied chiefs in the context of Fijian culture and administration (Nayacakalou 1975; Walters 1978; Sahlins 1981; MacNaught 1982; Kaplan 1988).

They, too, have largely ignored the inter-ethnic context and some agree with the above characterisation of the chiefs (Howard 1991; Kaplan 1993). My discussion will focus on the paradoxical duality of modern Fijian chieftainship in both affirming and mediating the ethnic divide.

For indigenous Fijians today, the value of chieftainship is reinforced by its potency in symbolising an idealised traditional way of life in communal attachment to the land, in contrast with the often denigrated money-based modern lifestyles to which individuals and households are increasingly drawn. This contradiction has long been intensified by the profound ethnic divide. The Indians' superiority in commercial enterprise has both created economic opportunities for Fijians and provoked their resentment. The ethnic anxieties gave chiefs, and the state institutions empowering them, political strength, and significance as guardians of cultural identity, enabling them to 
keep their pre-eminence in leadership for many years after the introduction of the popular vote, often co-opting trade unionists and other potential challengers (Norton 1990). For all Fiji's economic modernity, its extensive urbanisation, and the marked predominance of commoners in leadership and administration today, the chiefs still embody the most potent cultural capital where matters of ethnic interest are seen to be at stake and for the legitimation of political leadership.

While chieftainship is the strongest expression of Fijian ethnic difference, it is always potentially accommodating, not antagonistic and excluding. Indeed, many Indians are disposed to view Fijian chieftainship favourably, because Indians need chiefs for the containment of ethnic conflict, no less than chiefs need Indians to shore up their popular relevance as the symbolic anchor of ethnic identity. To understand the part chiefs have played in the control of ethnic conflict we must link the culture and the development of modern political economy, for it is particularly in this linkage that chieftainship acquired its conciliatory function.

The national importance of the chiefs was underlined by an unprecedented event in the recent negotiations to reform Fiji's constitution. The principal Indian political leader was invited to speak before that bastion of Fijian ethnic identity and privilege- the Bose Levu Vakaturaga, the Great Council of Chiefs, comprising 50 Fijian chiefs from the 14 provinces. Jai Ram Reddy's address helped secure the chiefs' assent to a proposal agreed between Fijian and Indian politicians to change the post-coup constitution which heavily discriminated against the Indians. The proposal, later endorsed by parliament, will allow political representation in proportion to ethnic demography, a bi-partisan cabinet, and special powers for the Council of Chiefs. ${ }^{1}$

The Council of Chiefs is the strongest embodiment of Fijian ethnic identity and power, as a central presence in the nation. Originating in the assembly of chiefs who ceded their islands to the British Crown, it was formalised by the early governors to facilitate indirect rule and to select Fijian representatives for the colonial parliament. By the end of the colonial era its membership had been broadened to include commoner leaders who had emerged in modern contexts. After the army coup, it was remade in its old form as an almost exclusively chiefly council. Although the meetings are solemnly publicised to the nation as affirmations of indigenous tradition, there is also a modern 
corporate tone: important looking men in suits and ties assembling at Suva's main convention centre with their smart briefcases. There are a few women, several of the highest rank.

The Council is a forum where aggressively racial opinions are sometimes voiced, and national leaders sternly questioned. However, as part of the institutional framework of 'the Fijian way of life' it also provides direct and vicarious experiences, which, by enhancing Fijian convictions of political and cultural strength in relations with other ethnic groups, have encouraged acceptance of the concessions their leaders make to those groups. This strength embodied in the council stands in a balancing relation to non-Fijian economic advantages.

The invitation to Jai Ram Reddy to speak before the Council was organised by the then Prime Minister, Sitiveni Rabuka, who once expelled Reddy and his colleagues from parliament at gunpoint. Before introducing Reddy, Rabuka urged the chiefs 'to think of the other communities': 'International law has given us [Fijians] the right to self-determination...to administer our own affairs and to protect our interests... But equally under international law...we also have an obligation to look after the minority communities'. He called for 'a common vision of Fiji...united in our diversity...bound together by a commitment of love and care for each other...' (Fiji Times, 7 June 1997:2).

Reddy's speech began with a moving declaration of respect and unity: 'The grandson of an indentured labourer answers the call of the Bose Levu Vakaturaga...And together we keep an appointment with history...to put the final seal on a troubled era and to open a new chapter of hope'. He addressed his hosts as 'the chiefs not just of the indigenous Fijians, but of all the people of Fiji'. He spoke of how the ancestral chiefs had overcome their conflicts and laid the foundations for the modern nation in the Deed of Cession: 'Just as [they] were called to bind together a divided people...so is this great council...called upon again...to be a foundation of unity for the islands your ancestors set on the road to modern nationhood'. In suggesting the development of a 'partnership' between Indian and Fijian, Reddy assured the chiefs that 'we honour your place, and the place of your people, as the first inhabitants of Fiji...We seek not to threaten your security but to protect it...For in your security lies the basis for our own' (Fiji Times, 7 June, 1997).

The occasion was widely acclaimed in Fiji as a defining event, not just in the process of post-coup rapprochement, but for the larger quest to construct a political community reconciling the principle of 
indigenous primacy with multi-ethnic government. It affirmed the place of chieftainship in inter-ethnic accommodation, projecting for the national consciousness an image of complementarity and mutuality across difference.

\section{Chieftainship and the control of militant ethnicity}

The chiefs' approval of reform muted the voice of ethnic chauvinism. There were protest rallies by the 'Viti National Union of Taukei Workers' and the 'Indigenous Rights Movement', one speaker warning that 'the lewe ni vanua [the people of the land] will now turn against their chiefs, because they have betrayed the indigenous peoples' trust' (Fiji Times and Daily Post, 9 June, 1997). But the most significant feature of these challenges was that very few people took part.

The potential for a chauvinist challenge to his leadership had nonetheless inhibited Rabuka during his dialogue with Reddy. He swung repeatedly between ethnic and national visions, earnestly affirming a goal of power sharing, but later declaring he could only agree to change if it strengthened Fijian dominance. His popularity in the Fijian constituency remained based on his charismatic warrior action in pursuit of this power, but under the pressure for reforms, he has been trying to re-make himself as a national leader. As a commoner he has no basis of legitimacy for inter-ethnic 'bridging' actions, therefore he has had to rely on the chiefs to validate the compromise with Indian leaders, just as he depended on them to ratify his coup and secure his first regime, and to constrain the ethnic chauvinism inflamed by that crisis (Norton 1990). The Council of Chiefs later endorsed a new constitution and authorised the political party through which Rabuka has ruled.

At issue in all these episodes is the control of cultural capital, the discourses and relationships with which affirmations of ethnic identity can be made and manipulated. Discourses to rival modern chieftainship in the assertion of Fijian identity have usually remained marginal voices, despite stressful economic and social changes evidenced in urbanisation, rural land shortages, and local landowner protests, that might be expected to energise stronger expressions of ethnic militancy. A major reason for this is that chiefs remain firmly positioned in the hierarchical relationships of traditional groupings which continue to be at the centre of most Fijian social and cultural life (Norton 1993). The most progressive political group to challenge Rabuka has been careful to show its respect to chiefs. Although initially promoted as the party 
that would appeal to educated urban commoners on issues linking them with non-Fijians, it relies on traditional relationships and provincial loyalties for election campaigning. Prominent chiefs are among its most vocal leaders, and its commoner leaders have been quick to reprove Rabuka for insufficient consultation with the Council of Chiefs (Norton 1994).

What is most remarkable about Fiji is not that the popular interests shared across ethnic difference have yet to be given an effective political voice, but that antagonistic ethnic movements have not emerged more strongly than they have. The predominant pattern in the expression of ethnic difference and opposition has been an asymmetric complementarity and accommodation, rather than an antagonistic schism. Two factors have especially contributed to this. First, land sharing has been pivotal in shaping inter-ethnic relations at grassroots and national levels. It is an ongoing negotiable relationship, in which chiefs have played a major part. Second, the cultural logics and social forms of Fijian political life, centring on chieftainship, have constrained antagonistic ethnicity and facilitated conciliatory dialogue with Indian leaders.

\section{The chiefs in the political economy of colonial Fiji}

In the first 50 years of colonial government, many chiefs enjoyed power in a system of indirect rule which was designed to supervise Fijians in an administrative quarantine from the plantation economy. By the 1930s this system had been wound down, and the chiefs were marginalised in local government by the extended responsibilities of British district administrators (MacNaught 1982, Norton 1990). Yet it was at this time that chiefs began, under pressure from the colonial government, to assume a place in the management of the economy.

The Australian company controlling the sugar industry was remaking its plantation proletarians into smallholder peasants under contract to supply cane to the mills. After carving its own estates into thousands of tiny tenancies, the company relied on new farmers securing leases from Fijian clans. However, this movement clashed with a growing Fijian interest in cash cropping as the government began to encourage 'individualism...to fit the Fijian for competition with his Indian neighbour' (Fletcher 1932).

As Fijians exploited tenant vulnerability by encouraging bribes and threatening not to renew leases, colonial officials viewed their new 'land consciousness' as a threat to the Indian settlers (Barton 1936). 
The company warned that 'any question of control of the land situation getting into the hands of the original owners must only end in calamity for all' (CSR 1934). ${ }^{2}$ These concerns were reinforced by the English crusader for Indian welfare and friend of Gandhi, Charles Andrews, who concluded after his 1936 visit that many Indian farmers faced dispossession, and that 'the whole fabric of the sugar industry is in danger of collapsing' (Andrews 1936). The sense of urgency was intensified also by pressures from the Government of India in response to demands from Gandhi's movement.

The governor, wanting to avoid 'an imposed solution', was convinced that 'the problem should be faced... while the Fijians still... rely upon their chiefs to decide for them' (Richards 1937). Within months of Andrews' visit, he relied on the most influential chief, Ratu Sukuna, to persuade the Council of Chiefs, and the provincial councils, to allow government to manage the leasing out of clan lands not required for members' use. Sukuna preached to his fellow chiefs on the wisdom and morality of sharing land with the Indians from whose labour 'much of our prosperity is derived... The owner of property has an important duty to perform... Bear in mind the story of the talents: whoever utilises what is given him will be given more. He who fails to use what he has, will lose all...It is therefore the bounden duty of landowners to utilise what they possess for the benefit of all.' Sukuna urged an end to unethical practices that were damaging the morality and dignity of Fijians and their culture: 'The land can only be fairly leased if this is regulated by the government...We shall receive more rents for there will be no waste land. We will live peacefully with our neighbours... and we shall have dissipated causes of evils that are now giving us a disreputable name' (Sukuna 1936).

Sukuna warned the chiefs that if they rejected his proposal, 'our house will be forcibly put in order [from] without'. His success in winning their assent was hailed as a breakthrough for economic development, and the chiefs were praised for their 'act of loyalty and trust' and their 'statesmanlike attitude towards the general affairs of the colony' (Barton 1936:7). Sukuna was soon conceding that in the cane areas Indian interests should be paramount (Administrative Officers' Conference 1944). He had earlier insisted that 'the Indian community, having shown us the way, can hardly expect to continue to hold all the land in the sugar districts where the plough mints money' (Legislative Council Debates 1933:301). 
The strongest expression of indigenous identity, chiefly leadership, had become a support for Indian prosperity. Central to this paradoxical link was the relationship the Deed of Cession had created between the chiefs and the British Crown, a bond of mutual commitment that established their collective authority in indigenous leadership, and, by binding the chiefs so strongly to the colonial state, helped to secure the Indians' position. On Sukuna's death, Vishnu Deo, the senior Indian political leader, lamented that 'the Indian community had lost a very good friend' (Fiji Times, 31 May 1958:1).

The potential conflict between the chiefs' decision and popular Fijian opinion is reflected in protests at the time by the exiled millenarian leader Apolosi Nawai 'The chiefs...have spoiled much of the land of their people and have given away many leases to Indians...All the good lands have been taken by Indians.' Now, with his release impending, Apolosi sent to his expectant followers a 'Proclamation of the New Era', announcing momentous events to come, including the destruction of 'the haughty chief'. He was confined to Suva and soon returned to exile.

\section{The chiefs in inter-ethnic relations}

For a brief time, the chiefs themselves were seen to pose the threat of disaffection. Their cooperation had become essential just as their status and authority had been greatly diminished, with some senior chiefs enduring a humiliating subordination to young European district officers. In this contradictory conjuncture, the chiefs' grievance was redressed by a new governor who worked with Sukuna to elevate their position, in a restored system of 'indirect rule'. In justifying this regressive move to the Colonial Office, the governor insisted that it was 'urgently necessary to broaden the base of Native collaboration'. He warned 'Fijians have political representation...but no direct responsibility or authority...If this does not produce irresponsible nationalism or racialism it will be surprising' (Mitchell 1943). ${ }^{3}$

Leading chiefs were placed in a stronger position in the state than ever before. The Council of Chiefs was made, in effect, a 'board of directors', controlling appointments to the Fijian Affairs Board. Sukuna became the first non-European in the colonial cabinet as executive head of a system of administration designed to confine as many Fijians as possible to a communal village life. The liberal philosophy of the 1930s had been reversed. When Sukuna was first appointed to the Legislative Council, colonial officials hoped he would 
help guide the Fijians in 'their transition to individualism' (Secretary for Native Affairs 1932). He now governed them with the conviction that they were 'still at heart subsistence villagers' (Norton 1990:46).

The new paternalism held contradictory meanings for the Fijian people. Many resented it for impeding free movement for work and residence. However, as Indian demographic superiority grew, and as the prospect of self-government loomed, the strength of the new institutions and of the chiefs in the state, gave them a reassuring symbolic importance. Indeed, it is one of the ironic twists of Fiji's history that the obstacles the Fijian administration placed in the way of Fijian economic advancement, helped to strengthen anxieties which gave the system value, as a framework and symbol of ethnic solidarity and political strength, against the perceived threat from the economically more successful Indians. For Fijians the postwar era was marked by a protective fusion of chieftainship, the state, and ethnic identity.

Yet in the context of inter-ethnic relations the chiefly élite assumed an identity as mediators and conciliators, no less than as ethnic boundary markers and rallying points of ethnic solidarity. This dual identity was encouraged by the new postwar colonial ideology. The empowering of leading chiefs as a 'corporate' ethnic élite governing a still largely segregated Fijian populace, occurred as the British Government remade its philosophy of rule, proclaiming a mission to encourage among colonial subjects everywhere a sense of national identity in preparation for self-government.

An annual holiday was introduced to celebrate the anniversary of the chiefs' gift of their islands to the British Crown. Until the 1950s this celebration was an affair between government and the Fijians. Now the occasion was to be commemorated 'not as a Fijian day, but as Fiji's day'. The Deed of Cession was made sacred as having secured peace and civilisation, marking the ancestral chiefs' commitment to the development of Fiji as a modern nation. Cession Day, Governor Garvey declared, was to be 'a focal point for the spirit of unity...[We] must think not as Fijians, Indians or Europeans, but as one' (Fiji Times, 29 September 1955:4-5, 6 November 1953:4). For the first time strong official efforts were made to inculcate in Indians a sense of belonging and importance (Administrative Officers' Conference 1953).

Chiefs in the Fijian Administration, or district officers in mainly Indian areas, assumed prominent roles in celebrations and festivals, and were drawn into relations with Indians as patrons or officebearers in local social or sports clubs, or as chairmen of town boards. 
Ties between mainly Indian organisations and Fijian chiefs became important as affirmations of the growth of a multi-ethnic society. There was, in these bonds, a sense of reconciliation between the 'foreign' agents of economic modernity and the élite custodians of an indigenous culture and political strength upon whose goodwill all ultimately depended. Both A.D. Patel and Vishnu Deo, the principal Indian leaders, agreed that Fijian interests should be paramount in government (Legislative Council Debates 1944:44, 1946:211, 1947:112, 1948:219). What most gave significance to the process of inter-ethnic bridging were the problems of land, which, while being a chronic source of ethnic tension, also encouraged negotiation and accommodation at both the local and national levels.

Thus it is another of Fiji's historical ironies that the immigrant Indians, emancipated from the ancient caste system, and developing an egalitarian society among themselves (Mayer 1973; Jayawardena 1975, 1980; Kelly 1991), were compelled by economic interests to come to terms with a new order of ascriptive difference and inequality-as dependent vulagi (guests) to their taukei hosts and patrons. For no other overseas Indian community did cultural and economic difference become the basis for an inter-ethnic system. The inequality in control of the means of production, and in associated forms of social deference, was offset by the material gains and by a conviction of cultural superiority. A contradiction soon emerged between the universalist egalitarian ideals adopted from Gandhi's movement for political agitation in Fiji, and the benefits accruing to Indians from the preservation of Fijian village 'communalism' within the framework of chiefly authority. Land leases were readily available and cheap to the Indian farmers and shopkeepers, to the extent that the taukei owners remained docile subsistence village folk little in need of money incomes, as most did until the 1970s. In the last decades of colonial rule, paternalistic Fijian administration was effectively a subsidy to Indian peasant welfare (and CSR company profits). Indeed of all overseas Indian populations descended from indentured workers, Fiji's has been one of the most economically successful (Subramani 1995).

The dual identity of leading chiefs as both ethnic and national figures is highlighted in the manner in which Sukuna is now revered on 'Ratu Sukuna Day' instigated by the Council of Chiefs several years after the army coups. The greatest chief of the colonial era is now 
exalted as a model of Fijian leadership for the national society, symbolising a way in which Fijian 'tradition' (or 'neo-tradition') might be incorporated into the core of a national political culture.

Sukuna represents the idealisation of high chiefs as figures of unassailable strength and dignity, representing and protecting Fijians, their land and culture in the modern world. Yet he also symbolises the role a chiefly leader should play in bridging the ethnic divide: 'Ratu Sukuna, the man who graced a nation. This man of noble birth carried out deeds with even greater nobility, without motive against any race in Fiji's multiracial society' (Fiji Times, 29 May 1995:1). On Sukuna Day in 1995, as public hearings for the constitutional review began, Rabuka's press statement intoned: 'The unity and sanctity of traditional Fijian society was always his first and foremost interest...But at the same time it was clear to him that Fijians would have to adjust to coexistence with other communities...All share a common wish to live peacefully... and to contribute to the development of Fiji' (Fiji Times, 29 May 1995:1).

A major outcome of the military coups has been a greater prominence of commoners in political leadership. The leading figures in Rabuka's government have been mostly commoners, and he has often displayed charismatic authority and skill in influencing decisions of the Council of Chiefs. Yet it is also clear that in the postcoup political process the chiefs have become more significant in the national domain. The part played by the Council in the recent constitutional reform highlighted this role, and the iconic Sukuna symbolically affirms it.

\section{Three models for nationhood}

Post-coup debate about how to make the nation revolves around three models or 'discourses'. At one extreme is the ethno-nationalist vision: an antagonistic and exclusionary ethnicity affirmed by some Fijian individuals and groups against Indians, such as the Taukei Movement launched for the street marches and violence that influenced the staging of the army coups. The proponents have typically been commoners. At the other extreme, a 'universalist' vision of equivalence among the citizens as workers, farmers, and consumers, is held by many leaders (mainly Indians) in the labour movement, by most of the Indian religious and political groups, some churches, and by some Fijians and others in the urban middle class. Its leading 
political proponent, Mahendra Chaudhry, was marginalised in the negotiations for constitutional reform, and another prominent advocate, Imrana Jalal, recently lamented that 'we still remain communities living side by side rather than with each other' (Fiji Times, 19 June 1997:7).

The prevailing model of the nation affirms an asymmetric complementarity linked with the role of chieftainship in the management of ethnic relations. The records of the Constitutional Review Commission show that most Fijian submissions did not express an 'antagonistic ethnicity', but a theme of accommodation and inclusion. They stressed the idea of a complementarity based on preserving Fijian political pre-eminence in some form. Although the petition of Rabuka's own party emphasised popular distrust of Indians and insisted on preserving taukei dominance, the Council of Chiefs declined to endorse it, and the party leaders themselves stressed that their document was a starting position from which compromise would be negotiated, as indeed it was.

\section{Conclusion}

The colonial legacy for ethnic relations in post-colonial Fiji has two dimensions. Most obvious is the reinforcement of the ethnic divide marked by persisting differences and inequalities in economy, culture, and social relations. In political life these differences have outweighed people's shared interests as workers, farmers, and consumers. The other colonial legacy, less recognised, is the one with which the postcolonial political process has now strongly reconnected: cultural codes and social structures that facilitate mediation and accommodation across difference.

The colonial rulers encouraged the development of a chiefly élite enjoying a privileged position in the state and embodying core values of indigenous Fijian culture. Yet chiefly political privilege has not inevitably been equated with Fijian ethno-nationalism. On the contrary, the formation of the chiefly élite facilitated the growth of a national political economy, and inhibited potentials for antagonistic ethnicity. The significance of the chiefs in the national political process has been their paradoxically dual position as, on the one hand, ethnic boundary markers and rallying figures in the occasional affirmation of indigenous Fijian solidarity in opposition to Indians, and on the other hand, as mediators of that division, reconcilers of the conflicting 
demands of ethnic and national arenas. This accommodation was favoured precisely by the manner in which Fijian ethnic identity and leadership were constituted from the late colonial period on the basis of the privileged relation between chieftainship and the state.

Of the four principal chiefs who dominated the Council of Chiefs and Fijian political leadership after Sukuna's death, only Ratu Sir Kamisese Mara survives. Both he and the late Ratu Sir Penaia Ganilau played a crucial part in moderating the impact of the Taukei Movement and the military coups. Elected political leadership is now dominated by commoners or people of relatively low traditional rank. Yet the chiefs, particularly as the Council of Chiefs, still hold considerable power as the most potent source of legitimacy for the policies and actions of leaders and as holders of prerogatives in the state under the reformed constitution. They will control appointments of the president and vice-president, and of nearly half the seats in an upper house where they will hold veto power.

Of course, the circumstances of ethnic relations today are very different from those in which the forms of Fijian leadership and ethnic identity I have been describing were shaped. The inter-ethnic role of the chiefs was linked with a pattern of complementarity supported in large part by a substantial ethnic separation in economy. There is now an increasing competition for jobs, land, and other economic resources. A critical question for Fiji's future is whether the chiefs will continue to act as conciliators, or whether, as this competition intensifies, they will align with the aggressively ethnicist styles of leadership they have in the past helped to subdue.

\section{Notes}

1 The reforms introduce some common roll seats, complementing a majority of communal seats, as well as allocating the latter roughly in proportion to ethnic demography. The offices of President, VicePresident and Prime Minister will no longer be reserved for Fijians (Parliament of Fiji 1996, 1997; Lal 1997). Several factors pushed the leaders towards an accord. Rabuka must nurture a stagnating national economy dependent on the resources of non-indigenous people and foreign investors. Since the coups, one in seven Indians have emigrated, to the great detriment of all Fiji. On the other hand, this exodus helped give Fijians a demographic edge that emboldened their leaders to agree to changes that will allow an Indian share in government. Further inducements were the wish for readmission to the Commonwealth and pressures on human 
rights issues from major foreign aid givers and trade partners. While all these factors were important, the rapprochement was enabled by features of Fijian leadership discussed here.

2 By 1934, 4,600 farmers were tenants of Fijians, and 4,100 were company tenants (Lal 1992:100).

3 Sukuna's ambivalence toward the British began with his rejection on racial grounds when as a young Oxford student he tried to enlist for World War I. At the height of his career he united with Indian leaders against discriminatory legislation, had a close friendship with a leading Indian critic of colonial rule, and was sympathetic to striking Indian cane farmers. Continuing official anxiety about Fijian loyalty is revealed in Governor Freeston's urgent request to London for funds to rebuild the leading Fijian school. He warned that dissatisfaction 'was reaching such a pitch as to threaten the longstanding Fijian loyalty to

government...Further procrastination will have disturbing political consequences' (Freeston 1949).

\section{References}

Administrative Officers' Conference, 1944. Fiji National Archives CSO files, FSO/104.

—, 1953. Fiji National Archives F4/3/7-5.

Andrews, C.F., 1936. Report to Government of Fiji, May 1936, CO83/215, 85038/36. AJCP Reels 4168 and 4169, PRO London.

Barton, L., 1936. Acting Governor Luxon Barton to Secretary of State for Colonies 31/10/1936, PRO London CO83/215/15.

CSR (Colonial Sugar Refining Company Ltd), 1934. General Manager, Sydney, to Governor of Fiji 23/2/1934. PRO London CO83/207/9.

Fletcher, M., 1932. Governor M Fletcher to Secretary of State for Colonies 26/1/1932, PRO London CO 83 196/7.

Freeston, B., 1949. Freeston to Secretary of State for Colonies 12/1/ 1949, Fiji National Archives CSO files, F28/225.

Howard, M., 1991. Fiji: Race and Politics in an Island State, University of British Columbia Press, Vancouver.

Jayawardena, C., 1975. 'Farm, household and family in Fiji Indian rural society (Part 1)', Journal of Comparative Family Studies, 6(1):7488 .

1975. 'Farm, household and family in Fiji Indian rural society (Part 2)', Journal of Comparative Family Studies, 6(2):209-221.

_ 1980. 'Culture and ethnicity in Guyana and Fiji', Man, 15:430450. 
Kaplan, M., 1988. Land and sea and the new white men: a reconsideration of the Fijian Tuka Movement, PhD thesis, Department of Anthropology, University of Chicago.

_ 1993. 'Imagining a nation: race, politics, and crisis in postcolonial Fiji', in V.Lockwood, T.Harding, and B.Wallace (eds), Contemporary Pacific Societies, Prentice-Hall, New Jersey, 43-54.

Kelly, J., 1991. A Politics of Virtue: Hinduism, Sexuality, and Countercolonial Discourse in Fiji. University of Chicago Press, Chicago.

Lal, B., 1992. Broken Waves: a history of Fiji in the 20th century, University of Hawaii Press, Honolulu.

— 1997. 'Towards a united future: report of the Fiji Constitution Review Commission', Journal of Pacific History, 32(1):71-84.

Lawson, S., The Failure of Democratic Politics in Fiji, Clarendon Press, Oxford.

MacNaught, T., 1982. The Fijian Colonial Experience, Pacific Research Monograph No.7, Australian National University, Canberra.

Mayer, A., 1973. Peasants in the Pacific, Routledge \& Kegan Paul, London.

Mitchell, P., 1943. Sir Phillip Mitchell to Secretary of State for Colonies 15/4/1943, 16/7/43. PRO London CO/83 236/15.

Nayacakalou, R., 1975. Leadership in Fiji. Oxford University Press, Melbourne.

Norton, R., 1990. Race and Politics in Fiji (second edition),University of Queensland Press, St Lucia .

- 1993. 'Culture and identity in the South Pacific: a comparative analysis', Man, 28(4):741-59.

1994. 'Ethnic conflict and accommodation in post-coup Fiji', in

G.Hage, J.Lloyd and L.Johnson, Pluralising the Asia-Pacific (Volume 3 of Communal/Plural), Research Centre in Intercommunal Studies, University of Western Sydney, Sydney: 43-64.

Parliament of Fiji, 1996. The Fiji Islands-towards a united future,

Parliamentary Paper No 34 of 1996, Report of the Fiji Constitution Review Commission.

- 1997. Report of the Joint Parliamentary Select Committee on the Report of the Fiji Constitution Review Commission, Parliamentary Paper No 17 of 1997.

Richards, A., 1937. Governor Richards to Secretary of State for Colonies 30/12/37, PRO London CO83/222/8. 
Robertson, R., and Tamanisau, A., 1988. Fiji: Shattered Coups, Pluto Press, Sydney.

Sahlins, M., 1981. 'The stranger-king', Journal of Pacific History, 16(3):107-32.

Secretary for Native Affairs, 1932. Secretary of Native Affairs to Colonial Secretary 5/7/1932, Fiji National Archives, CSO CF38/1.

Subramani, 1995. Altering Imagination, Fiji Writers' Association, University of the South Pacific, Suva.

Sukuna, R. L., 1936. Ratu Lala Sukuna to Council of Chiefs, Bau 31/ 10/36, PRO London CO83215/15.

Sutherland, W., 1992. Beyond the Politics of Race: an alternative history of Fiji to 1992, Political and Social Change Monograph 15, Australian National University Research School of Pacific and Asian Studies, Canberra.

Walters, M., 1978. 'An examination of hierarchical notions in Fijian society: a test case for the applicability of the term 'chief", Oceania, 49(1):1-19. 